\title{
Plasma-assisted synthesis of noble nanoparticles coated with hyaluronan: chemico-physical characterization and safety assessment
}

\section{Viviana Caruso}

University of Catania

\section{Delphine Merche}

Université Libre de Bruxelles

Joffrey Baneton

Université Libre de Bruxelles

Alp Ozkan

Université Libre de Bruxelles

\section{Valentina Greco}

Consorzio Interuniversitario di Ricerca in Chimica dei Metalli nei Sistemi Biologici - Bari

\section{Lorena Cucci}

University of Catania

\section{Pietro Amico}

Fidia Farmaceutici S.p.A. https://orcid.org/0000-0001-7288-2194

\section{Michele Caputo}

Fidia Farmaceutici S.p.A.

Rosanna Inturri ( $\nabla$ rinturri@fidiapharma.it)

Fidia Farmaceutici S.p.A. https://orcid.org/0000-0002-2260-7773

\section{Susanna Vaccaro}

Fidia Farmaceutici S.p.A.

\section{François Renier}

Université Libre de Bruxelles

Cristina Satriano

University of Catania

\section{Article}

Keywords: NMR, ATR-FTIR, AFM, TEM, antibacterial, HUVEC, collagenase, gold nanoparticles, silver nanoparticles 
DOI: https://doi.org/10.21203/rs.3.rs-1236631/v1

License: (a) (i) This work is licensed under a Creative Commons Attribution 4.0 International License. Read Full License 
Plasma-assisted synthesis of noble nanoparticles coated with hyaluronan: chemico-physical characterization and safety assessment

Viviana C.L. Caruso ${ }^{1}$, Delphine Merche ${ }^{2}$, Joffrey Baneton ${ }^{2}$, Alp Ozkan ${ }^{2}$, Valentina Greco ${ }^{1}$, Lorena Cucci ${ }^{1}$, Pietro $\mathrm{Amico}^{3}$, Michele Caputo ${ }^{3}$, Rosanna Inturri ${ }^{3 \#}$, Vaccaro Susanna ${ }^{3}$, François Reniers ${ }^{2}$, Cristina Satriano ${ }^{1 *}$

${ }^{1}$ Nano Hybrid bioInterfaces Lab (NHIL) at the Department of Chemical Sciences, University of Catania, viale Andrea Doria, 6, 95125 Catania, Italy.

${ }^{2}$ Analytical and Interfacial Chemistry, Université Libre de Bruxelles, 1050 Brussels, Belgium

${ }^{3}$ R\&D Unità locale Fidia Research Sud, Contrada Pizzuta, 96017 Noto (SR), Italy

${ }^{*}$ Corresponding author

\# Co-corresponding author

Keywords: NMR, ATR-FTIR, AFM, TEM, antibacterial, HUVEC, collagenase, gold nanoparticles, silver nanoparticles.

\begin{abstract}
Nanosystems are rapidly gaining attention in the biomedical, chemical, material, computer and catalysis fields. Recent research has been focused on synthetic methods to decrease toxicity and side effects as compared to classic formulations. However, harmonization of the interpretative criteria of biological activity and strategies to improve the scalability of synthetic technologies are limited. The present work describes the use of atmospheric plasma as a promising strategy to produce size-controlled and safe noble nanoparticles, which did not show surface toxicity due to the absorption of chemicals during the synthesis reaction. Physisorption with Hyaluronic Acid was used to modulate nanoparticle aggregation kinetics and improve biological properties. Physico-chemical characterization was conducted using NMR spectroscopy, UV-visible and dynamic light scattering. Cytotoxicity on bacterial and Human Umbilical Vein Endothelial Cells was tested. The results demonstrated the efficiency of the plasma synthetic method to control nanoparticle size and toxicity selectively improving antibacterial activity against Gram-negative strain.
\end{abstract}




\section{Introduction}

Nanoparticles (NPs) obtained from noble metals (AuNPs and AgNPs) have a free energy surface that depends on temperature, Boltzmann's constant $\left(k_{B}\right)$, saturation of salt solutions $(S)$, molar volume $(v), \mathrm{pH}$ and liquid or

gas catalysis, which together define their chemico-physical and biological properties $\left(\Delta G_{v}=\frac{-k_{B} T \ln (S)}{v}\right)[1-3]$. Physisorption with hyaluronic acid (HA) with low $(200 \mathrm{kDa})$ molecular weight $(\mathrm{Mw})$ modulates their aggregation kinetic, prevents secondary collateral phenomena such as coagulation and coalescence and plays a crucial role in morphology, size and biological activity [4-8]. AgNPs and AuNPs represent the most industrially produced and commercialized nanomaterials; their properties are unique and applications are found in different fields including material science, biosensing, organic chemistry, biotechnology, high molecular sensitivity detection, optics, biosensors, computers, medicine, microbiology, and catalysis [3, 9]. Different approaches have been outlined to synthetize NPs, including chemicals, photo- and electro-chemical, extractive, and fermentative methods. The classical methods require high temperature, pressure and energy and involve the manipulation of hazardous chemicals with the need for complex purification steps, and the resulting products usually contain chemical contaminants. Moreover, extractive, and biological sources have a relatively slower rate $[10-14]$.

Here we propose the use of atmospheric plasma as an environmentally sustainable, low energy consumption, affordable and highly efficient method to produce size-controlled and safe noble nanoparticles, which did not absorb toxic chemicals on their surface during the synthesis reaction [15-19]. Cold plasma obtained at atmospheric pressure and room temperature results as being rich with energetic electrons that are capable of dissociating, exciting and ionizing gas molecules [20-22]. Typical reactions include the formation of a Reactive Oxygen and Nitrogen Species (RONS) discharge that can diffuse/dissolve into water during exposure and react with the water molecules, resulting in a cocktail of chemical species whose generation depends on the release of hydrogen ions; moreover, neutral gas molecules subjected to cold plasma treatment are transformed into their oxides and their products can react with hydroxyl radicals, to produce hydrogen peroxide in plasma activated water (PAW) at the gas/liquid interface [23]. PAW was used as the reducing agent for $\mathrm{Ag}^{+}$ or $\mathrm{Au}^{3+}$ ions from $\mathrm{Ag} / \mathrm{Au}$ salts to obtain $\mathrm{AgNPs}$ and AuNPs. 
Physisorption with Hyaluronic Acid (HA) at a low molecular weight (200 kDa) and conjugation with the GHHPHGK peptide through an amide bond $[24,25]$ were performed to improve pro-angiogenic activity [2628]. The GHHPHGK derives from GHHPH, a $67 \mathrm{kDa}$ peptide repeat present in histidine-proline rich glycoprotein (HPRG, Accession number: P04196, gene ID 3273) [29, 30]. The amide linkage protected the polymer from enzymatic degradation [31,32]. Successively cold plasma technology as used to synthetize coated noble nanoparticles. Physico-chemical characterization was conducted using NMR spectroscopy, UVvisible and dynamic light scattering [33]. The safety assessment of polymeric nanosystems was evaluated on bacterial strains and HUVEC cell lines; moreover, their capacity to have no effect collagenase activity was tested for their application in wound healing. The resulting NPs can represent a promising technology because of their biological activity, an effective drug delivery system and suitable pharmacokinetic biomodulators [34, 35].

\section{Materials and Methods}

\subsection{Chemicals}

HA 200 kDa (HA) was provided by Fidia Farmaceutici S.p.A. (Italy); Sodium hydroxide (NaOH) was purchased from Honeywell Fluka (USA); Silver nitrate $\left(\mathrm{AgNO}_{3}\right)$ purity $>99.0 \%$, sodium borohydride $\left(\mathrm{NaBH}_{4}\right)$ purity $\geq 99.0 \%$, D-(+)-glucose purity $\geq 99.5 \%$, Tetrachloroauric (III) acid trihydrate $\left(\mathrm{HAuCl}_{4} \cdot 3 \mathrm{H}_{2} \mathrm{O}\right)$ purity $\geq 99.9 \%$, tetrahydrofuran (THF) anhydrous, purity $\geq 99.9 \%, 1$-Hydroxybenzotriazole (HOBt), N,NDiisopropylethylamine (DIEA) Reagent Plus, $\geq 99.0 \%$, N-(3-Dimethylaminopropyl)-N'-ethylcarbodiimide hydrochloride (EDC $\cdot \mathrm{HCl}$ ) purity $\geq 99.0 \%$, acetone purity $\geq 99.9 \%$, Phosphate Buffer Saline (PBS), deuterium oxide $\left(\mathrm{D}_{2} \mathrm{O}\right) 99.9 \%$ atom \% D. Water was deionized (resistivity $>18.2 \mathrm{~m} \Omega \mathrm{cm}$ at $\left.25^{\circ} \mathrm{C}\right)$ and purified using a milli-Q unit (Milli-Q plus, Millipore, France). Glassware was first cleaned with aqua regia ( $\mathrm{HCl}: \mathrm{HNO}_{3}, 1: 3$ volume ratio) and then rinsed with water before starting. 


\subsection{Synthesis of Hyaluronic Acid-GHHPHGK conjugate}

The conjugation between hyaluronic acid (HA $200 \mathrm{kDa}$ ) and the peptide GHHPHGK (Glycine-HistidineHistidine-Prolyne-Histidine linked to Glycine-Lysine- $\mathrm{NH}_{2}$ ) was obtained through an amide bond [25]. For the reaction, $0.372 \mathrm{~g}$ of HA were suspended in $15 \mathrm{~mL}$ of THF (Tetrahydrofuran, Sigma Aldrich, Italy), under stirring at $4{ }^{\circ} \mathrm{C}$. Then, $0.150 \mathrm{mg}$ of HOOBt (3-Hydroxy-1,2,3-benzotriazin-4(3H)-one, Sigma Aldrich, Italy), previously dissolved in $15 \mathrm{~mL}$ of THF: $\mathrm{H}_{2} \mathrm{O}$ (1:1); $0.0566 \mathrm{~g}$ of DIEA (N,N-Diisopropylethylamine, Sigma Aldrich, Italy) previously dissolved in $7.5 \mathrm{~mL}$ of THF: $\mathrm{H}_{2} \mathrm{O}(1: 1)$, and $0.070 \mathrm{~g}$ of GHHPHGK-NH $\mathrm{N}_{2}$ previously dissolved in $700 \mu \mathrm{L}$ of $\mathrm{H}_{2} \mathrm{O}$, were added to this suspension. The reaction mixture was maintained under stirring at $4{ }^{\circ} \mathrm{C}$ for $30 \mathrm{~min}$. Then, $0.0165 \mathrm{~g}$ of $\mathrm{EDC} \cdot \mathrm{HCl}$ were dissolved in $1.4 \mathrm{~mL}$ of water and added to the reaction mixture. After $24 \mathrm{~h}$, the product was precipitated adding $300 \mathrm{~mL}$ of acetone. The precipitate was dissolved in a minimum volume of water $(65 \mathrm{~mL})$ and dialyzed against water by a dialysis tube (12-14 kDa cut-off); the dialyzed product was then lyophilized (Labconco, Freeze dry system, USA) [24].

\subsection{NMR analysis of the HA derivate}

1D and 2D ${ }^{1} \mathrm{H}-\mathrm{NMR}$ spectra were recorded at $500 \mathrm{MHz}$ on a Varian Unity Inova spectrometer (Varian, USA). The experiments were performed in $\mathrm{D}_{2} \mathrm{O}$ at $27^{\circ} \mathrm{C}$ and the chemical shifts reported as $\delta$ (ppm), referenced to the resonance of residual HOD. Unequivocal assignments of ${ }^{1} \mathrm{H}$ resonances were supported by mono- and bidimensional experiments gCOSY and gHSQC.

The amount of GHHPHGK peptide $(p)$ conjugated with HA was determined from the ratio between the integration value of the signal of the acetyl groups of $\mathrm{HA}$ and the $-\mathrm{CH}_{2}$ Lysine signal or that of the $\mathrm{H}-2$ or $\mathrm{H}-$ 5 signals of the Histidine imidazole ring.

\subsection{Synthesis of AgPNs and AuNPs}

\subsubsection{Wet chemical synthesis of AgNP and AuNP and HA conjugation}

The bare silver nanoparticles (AgNPs) were synthetized following the method described by Mavani et al. (2016) [36] Briefly, a solution of $1 \mathrm{mM} \mathrm{AgNO}_{3}$ was added with $2 \mathrm{mM} \mathrm{NaBH}_{4}$, see equation (1). The reaction was maintained in an ice bath and under stirring $(200 \mathrm{rpm})$ for 45 minutes. Naked-eye detection was used to confirm the end of the reaction with the chromatic transition of the solution from colourless to yellow. 


$$
\mathrm{Ag}^{+}+\left[\mathrm{BH}_{4}\right]^{-}+3 \mathrm{H}_{2} \mathrm{O} \stackrel{0^{\circ} \mathrm{C}}{\longrightarrow} \mathrm{Ag}^{0}+\mathrm{H}_{3} \mathrm{BO}_{3}+3.5 \mathrm{H}_{2}
$$

The bare gold nanoparticles (AuNPs) were synthetized starting from a $0.5 \mathrm{mM} \mathrm{HAuCl}_{4}$ aqueous solution by adding a $7 \mathrm{mM} \mathrm{NaOH}$ and $5 \mathrm{mM}$ Glucose solution, see equation (2). The reaction at $25^{\circ} \mathrm{C}$ occurred in 1 minute and its end was detected by the naked eye thanks to the chromatic transition from yellow to purple red.

$$
2 \mathrm{Au}^{3+}+3 \mathrm{C}_{6} \mathrm{H}_{12} \mathrm{O}_{6}+6 \mathrm{OH}^{-} \stackrel{25^{\circ} \mathrm{C}}{\longrightarrow} 3 \mathrm{C}_{6} \mathrm{H}_{12} \mathrm{O}_{7}+3 \mathrm{H}_{2} \mathrm{O}+2 \mathrm{Au}^{0}
$$

In order to obtain the coated products, the AgNPs and AuNPs were synthetized solubilizing the $\mathrm{AgNO}_{3}$ and $\mathrm{HAuCl}_{4}$ salts in a $0.2 \% \mathrm{w} / \mathrm{v} \mathrm{HA} / p \mathrm{HA}$ water solution.

\subsubsection{Cold-plasma torch synthesis of AgNP and AuNP and HA conjugation}

The plasma method to synthetize AgNPs and AuNPs used atmospheric pressure microplasma which can form the radical species $\mathrm{OH}^{*}$ that acts as the reducing agent activator for the corresponding metal reduction [17]. Argon (Ar) at a flow rate of $25 \mathrm{sccm}$ was injected from a pressurized stainless-steel capillary tube $(0.6 \mathrm{~mm}$ inner diameter) whose tip was positioned approximately $2 \mathrm{~mm}$ above the plasma-liquid interface (Fig. 1). 


\section{a) Plasma technology}

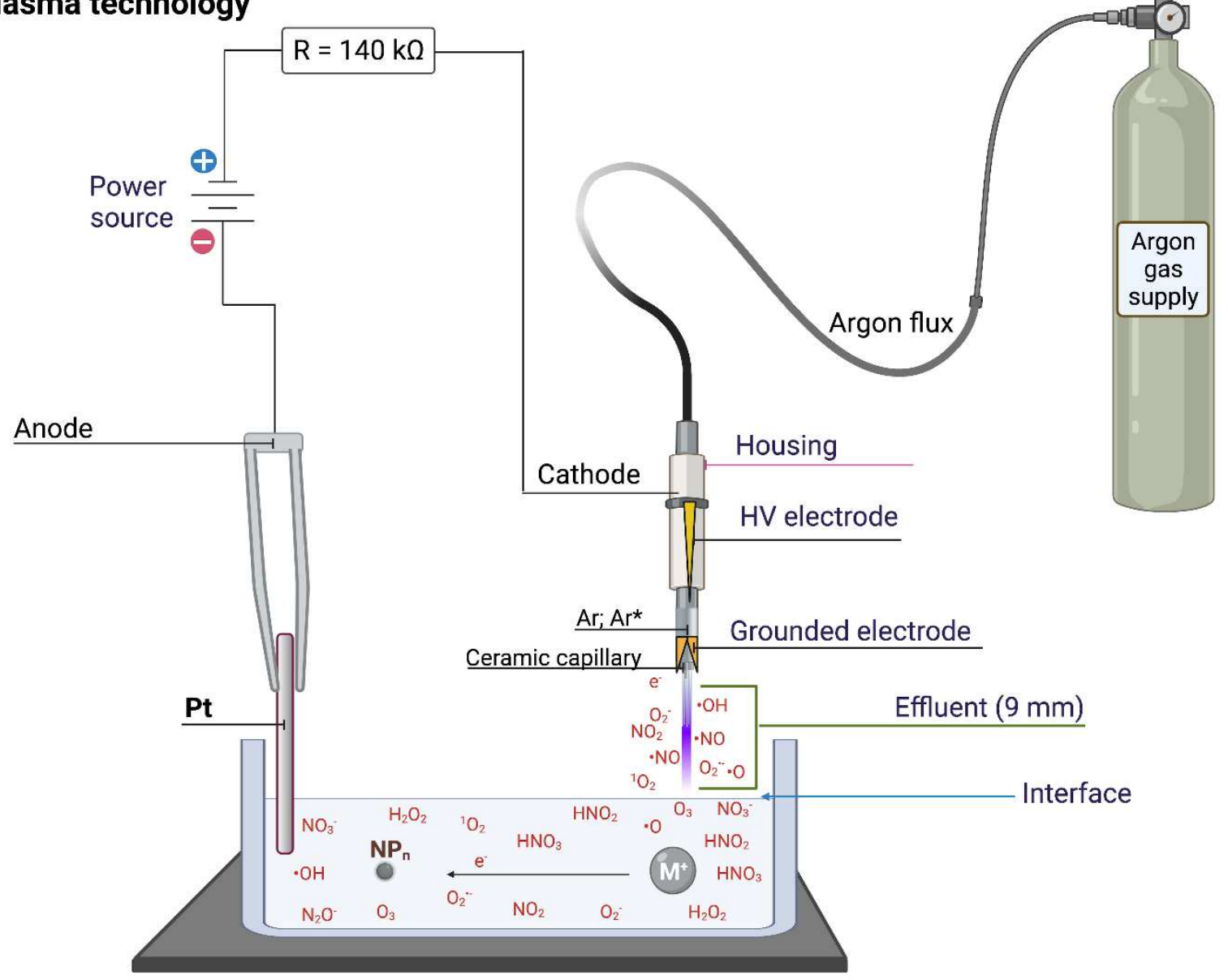

\section{b) Nanoparticle aggregation mechanism}
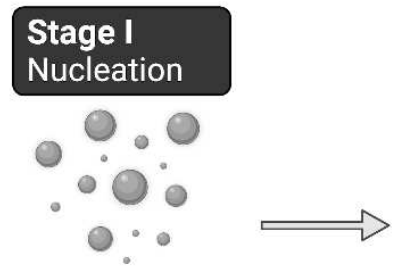

\section{Stage II \\ Fast growth}

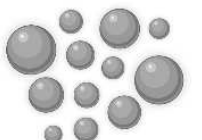

\section{Stage III}

Slow further growth

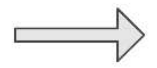

Stage IV

Fast final growth

Figure 1. a) Schematic representation of nanoparticle synthesis using atmospheric pressure microplasma as the reducing agent activator. The formation of AuNPs consists of four steps: i) nucleation, about 1/5 of metal particles present as gold salt start interacting with each other in the first 20s; ii) growth, AuNPs size increases to $5.2 \mathrm{~nm}$; iii) slow further growth, AuNPs size increases with a controlled growth mechanism where the limiting factor is the metal concentration within the solution; iv) fast final growth, a rapid increase in AuNPs size from 5-5.2 nm to $7.7 \mathrm{~nm}$ determined by an autocatalytic reduction on their surface [37]. In the absence of a stabilizing agent such as hyaluronic acid, which physioabsorbs on the surface of aggregating particles, the growth of nanoparticles continues even $24 \mathrm{~h}$ after the start of the reaction. The use of a stabilizing agent as a nucleation modulator is mandatory to regulate the size and kinetics of gold nanoparticle formation in aqueous media. The nucleation mechanisms have a substantial impact on gold nanoparticle bond length, causing it to decrease from $2.87 \AA$ (calculated on the bulk) to the range of 2.55-2.70 $\AA$. As the reaction progresses, the bond becomes shorter due to the increase in particle size and the decrement of the surface area per gold atom. A secondary mechanism also led to the formation of dimers $\left(\mathrm{Au}_{2} \mathrm{Cl}_{6}\right)$ and trimers, with the occasional formation of gold clusters like $\mathrm{Au}_{13}$, the principal cause of coalescence and often considered as an undesired species in reaction mixtures [1]. b) Schematic representation of nanoparticle formation mechanism. 
An electric charge of $3 \mathrm{~mA}$ (with a resistance value of $140 \mathrm{k} \Omega$ ) was applied to a $1 \mathrm{mM}$ solution of $\mathrm{AgNO}_{3}$ for 15 minutes at a temperature of $<5{ }^{\circ} \mathrm{C}$, without stirring. Product formation was observed by the naked eye thanks to a chromatic transition from transparent to yellow brown.

An electric charge of $5 \mathrm{~mA}$ (with a resistance value of $140 \mathrm{k} \Omega$ ) was applied to a $5 \mathrm{mM}$ solution of $\mathrm{HAuCl}_{4}$ for 15 minutes at a temperature of $<5{ }^{\circ} \mathrm{C}$, without stirring. Product formation was observed by the naked eye thanks to a chromatic transition from yellow to purple red.

For both reactions, a platinum (Pt) foil was immersed in the solution as a counter electrode to promote cathodic reduction reactions at the plasma-liquid interface.

In order to obtain the coated products, the AgNPs and AuNPs were synthetized solubilizing the $\mathrm{AgNO}_{3}$ and $\mathrm{HAuCl}_{4}$ salts in a $0.2 \% \mathrm{w} / \mathrm{v} \mathrm{HA} / p \mathrm{HA}$ water solution.

As required by some experimental methods, after washing with ultrapure water, the concentrated NPs were obtained by centrifugation for $15-20$ minutes at $15^{\circ} \mathrm{C}$ and $8000-13000 \mathrm{rpm}$ (Eppendorf Centrifuge 5417R, FA453011 Rotor, Italy). The NPs coated with HA were centrifuged for 4 minutes at $15{ }^{\circ} \mathrm{C}$ and $10000 \mathrm{rpm}$ using a filter with a $30 \mathrm{kDa}$ molecular weight cut-off (Merk Millipore, USA).

\subsection{Physicochemical characterization of bare and HA/pHA coated AgNPs and AuNPs}

\subsubsection{UV-Visible nanoparticle characterization}

UV-Visible characterization was conducted at $25^{\circ} \mathrm{C}$ using a Lambda2S spectrophotometer (Perkin Elmer, USA). The measurements were performed using quartz cuvettes ( 1.0 or $0.1 \mathrm{~cm}$ path length). The absorbance and maximum wavelength were recorded. The assay was performed in triplicate twice and the reproducibility of the synthesis was evaluated as a percentage of relative standard deviation (\% RSD), as given in equation (3):

$$
\% \operatorname{RSD}=\frac{\mathrm{SD}}{\overline{\mathrm{x}}} \times 100
$$

where $\bar{x}$ is the average value of the measured variable, and $S D$ is the standard deviation.

The theoretical size of NP diameters was calculated from equation (4) as described by Haiss et al. (2007) [38], considering each force involved in the system, including plasma frequency and collision frequency.

$$
\sigma_{e x t}=\frac{2 \pi}{|k|^{2}} \sum(2 L+1) \operatorname{Re}\left(a_{L}+b_{L}\right)
$$


where $\sigma_{\text {ext }}$ is the cross section of a spherical particle with $\mathrm{R}$ as the radius embedded in a medium with dielectric function $\epsilon_{m}$ at a defined wavelength $\lambda ; k=\sqrt[2]{\epsilon_{m} / \lambda}$ is the wave vector; $a_{L}(R, \lambda)$ and $b_{L}(R, \lambda)$ are the scattering coefficients in terms of Ricatti-Bessel functions.

\subsubsection{Dynamic light scattering nanoparticle characterization}

The NPs hydrodynamic diameter size was investigated by Dynamic Light Scattering (DLS), measuring the particle size distribution at $25{ }^{\circ} \mathrm{C}$ with a $650 \mathrm{~nm}$ light source (laser diode, $5 \mathrm{~mW}$ and photo multiplier tube detector) by using DLS HORIBA LB-550, USA [33]. The measurements were performed using quartz cuvettes (1.0 $\mathrm{cm}$ path length). The assay was performed in triplicate twice.

\subsubsection{ATR-FTIR nanoparticle characterization}

The chemical structure of the functional groups was determined by Fourier-transform infrared spectroscopy (ATR-FTIR) following the method described by Sanfilippo et al. (2020) [39]. Briefly, the silicon wafers are cut to give a surface of $0.8 \mathrm{~cm} \times 1 \mathrm{~cm}$ and washed with methanol and iso-octane. $100 \mu \mathrm{L}$ of the sample (HA, NP or HA-NP) were put on the cleaned silicon surface and left to dry at room temperature. The ATR-FTIR spectra was recorded using a Spectrum Two ${ }^{\mathrm{TM}}$ FTIR Spectrometer (Perkin Elmer, USA).

\subsubsection{Atomic Force Microscopy (AFM) nanoparticle characterization}

The surface morphology and nanomechanical properties were studied using Atomic Force Microscopy (AFM), following the method described by Gołek et al. (2014) [40]. Briefly, $10 \mu \mathrm{L}$ of NPs were put on freshly cleaved muscovite mica (Ted Pella, Inc.) and incubated at room temperature for 5 minutes. The mica surface was immediately imaged, after a drying treatment under a gentle nitrogen stream, subsequent to washing with ultrapure water. Scans were recorded using a Cypher atomic force microscope (AFM - Asylum Research, Oxford Instruments, Santa Barbara, CA), operating in a tapping-mode and furnished with a scanner at an XY scan range of 30/40 $\mathrm{lm}$ (closed/open loop). AFM images without filtering were obtained and produced with silicon tetrahedral tips, fitted on $30 \mathrm{~lm}$ long rectangular cantilevers (Olympus AT240TS, Oxford Instruments), 
with contact AFM operating in a constant force mode, with a nominal spring constant of $2 \mathrm{~N} / \mathrm{m}$ and driving frequencies of $70 \mathrm{KHz}$. NP size was analyzed with MFP-3DTM software.

\subsubsection{Diameter size determination by transmission electron microscope (TEM)}

The morphology, composition and size of the NPs were verified by means of a transmission-electron microscope (TEM) using a Philips CM20 microscope $200 \mathrm{kV}$ operating with a tungsten electron gun, using the method described by Haiss et al. (2014) [38]. The Feret diameter of the particles was determined automatically using "Image Tool” software.

\subsection{Biological properties of bare and HA/pHA coated AgNPs and AuNPs}

\subsubsection{Bacterial strains and culture conditions}

The strains used were Escherichia coli ATCC 9637 and Staphylococcus aureus ATCC 29213 from the Bacteriological Laboratory collection of Fidia Farmaceutici S.p.A. (Noto, Italy). For the assays, frozen stocks of each strain were retrieved from a $-80{ }^{\circ} \mathrm{C}$ freezer and plated on Mueller Hinton (MH) agar plates. After 24 h of incubation at $37{ }^{\circ} \mathrm{C}$ in aerobic conditions (Memmert incubator, $\mathrm{GmbH}+\mathrm{Co} . \mathrm{KG}$, Äußere Rittersbacher Straße), a single colony for each strain was picked to inoculate $10.0 \mathrm{~mL}$ of $\mathrm{MH}$ broth and incubated overnight $(16-18 \mathrm{~h})$ at $37^{\circ} \mathrm{C}$. The overnight broth cultures were then used for the assay.

\subsubsection{Agar diffusion assay}

The putative inhibitory activity of the NPs was investigated determining the zone of inhibition by the agar diffusion assay, modifying the method described by CLSI M7-A7 for bacteria [41]. Briefly, $200 \mu \mathrm{L}$ of each NP were deposited in $6.0 \mathrm{~mm}$ wells, previously punched into $\mathrm{MH}$ agar, where $100 \mu \mathrm{L}$ of tested bacterial suspension were spread at the concentration of about $1.0 \times 10^{5-6} \mathrm{CFU} / \mathrm{mL}$, determined spectrophotometrically (OD 630 , using a spectrophotometer Synergy HT, Bioteck, USA) [42]. After $24 \mathrm{~h}$ of incubation at $37^{\circ} \mathrm{C}$ under aerobic conditions, the inhibitory effect was detected by an inhibition zone around the wells. The chloramphenicol $\left(32 \mu \mathrm{g} \mathrm{mL}^{-1}\right)$ was used as the reference antimicrobial agent. The results were the mean of three individual experiments. The interpretative criteria used for the agar diffusion assay were as follows: very 
strong $=$ diameter of inhibition zone $\geq 18.0 \mathrm{~mm}$; strong = diameter of inhibition zone $(18.0 ; 13.0] \mathrm{mm}$; good $=$ diameter of inhibition zone $(13.0 ; 11.0] \mathrm{mm}$; weak = diameter of inhibition zone $(11.0 ; 9.0] \mathrm{mm}$; very weak $=$ diameter of inhibition zone $(9.0 ; 8.0] \mathrm{mm}$; no activity $=$ diameter of inhibition zone $<8.0 \mathrm{~mm}$. The chemically synthetized NPs were tested at the following concentration ranges: AgNP from $9.25 \mathrm{nM}\left(=1.05 \cdot 10^{-2} \mu \mathrm{g} / \mathrm{mL}\right)$ to $1.16 \mathrm{nM}\left(=1.31 \cdot 10^{-3} \mu \mathrm{g} / \mathrm{mL}\right)$; HA-AgNP from $14.0 \mathrm{nM}\left(=1.30 \cdot 10^{-2} \mu \mathrm{g} / \mathrm{mL}\right)$ to $1.75 \mathrm{nM}\left(=1.63 \cdot 10^{-3}\right.$ $\mu \mathrm{g} / \mathrm{mL})$; pHA-AgNP from $20.5 \mathrm{nM}\left(=1.66 \cdot 10^{-2} \mu \mathrm{g} / \mathrm{mL}\right)$ to $2.56 \mathrm{nM}\left(=2.08 \cdot 10^{-3} \mu \mathrm{g} / \mathrm{mL}\right) ;$ AuNP from 0.585 $\mathrm{nM}\left(=1.45 \cdot 10^{-5} \mu \mathrm{g} / \mathrm{mL}\right)$ to $0.07\left(=1.81 \cdot 10^{-6} \mu \mathrm{g} / \mathrm{mL}\right) ;$ HA-AuNP from $0.55 \mathrm{nM}\left(=1.37 \cdot 10^{-5} \mu \mathrm{g} / \mathrm{mL}\right)$ to 0.07 $\mathrm{nM}\left(=1.71 \cdot 10^{-6} \mu \mathrm{g} / \mathrm{mL}\right) ; \mathrm{pHA}-\mathrm{AuNP}$ from $0.24\left(=5.93 \cdot 10^{-6} \mu \mathrm{g} / \mathrm{mL}\right)$ to $0.03 \mathrm{nM}\left(=7.41 \cdot 10^{-7} \mu \mathrm{g} / \mathrm{mL}\right)$. The plasma synthetized NPs were tested at the following concentration ranges: AgNP from $5.82 \mathrm{nM}\left(=3.17 \cdot 10^{-4}\right.$ $\mu \mathrm{g} / \mathrm{mL})$ to $0.73 \mathrm{nM}\left(=3.96 \cdot 10^{-5} \mu \mathrm{g} / \mathrm{mL}\right)$; HA-AgNP from $5.51 \mathrm{nM}\left(=2.61 \cdot 10^{-4} \mu \mathrm{g} / \mathrm{mL}\right)$ to $0.69 \mathrm{nM}(=$ $\left.3.27 \cdot 10^{-5} \mu \mathrm{g} / \mathrm{mL}\right) ;$ pHA-AgNP from $3.60 \mathrm{nM}\left(=1.02 \cdot 10^{-4} \mu \mathrm{g} / \mathrm{mL}\right)$ to $0.45 \mathrm{nM}\left(=1.27 \cdot 10^{-5} \mu \mathrm{g} / \mathrm{mL}\right) ;$ AuNP from $29.80 \mathrm{nM}\left(=7.36 \cdot 10^{-4} \mu \mathrm{g} / \mathrm{mL}\right)$ to $3.72 \mathrm{nM}(=9.20 \cdot 10-5 \mu \mathrm{g} / \mathrm{mL})$; HA-AuNP from $19.54 \mathrm{nM}(=4.83 \cdot 10$ $4 \mu \mathrm{g} / \mathrm{mL})$ to $2.44 \mathrm{nM}\left(=6.04 \cdot 10^{-5} \mu \mathrm{g} / \mathrm{mL}\right) ; \mathrm{pHA}$-AuNP from $2.04 \mathrm{nM}\left(=5.04 \cdot 10^{-5} \mu \mathrm{g} / \mathrm{mL}\right)$ to $0.25 \mathrm{nM}(=$ $6.30 \cdot 10^{-6} \mu \mathrm{g} / \mathrm{mL}$; chloramphenicol was tested at the concentration range from 124 to $0.5 \mu \mathrm{g} / \mathrm{mL}$.

\subsubsection{Broth microdilution assay}

A broth microdilution assay using 96-well plates was performed for determining the MIC (Minimum Inhibitory Concentration) End Points for each NP against standard strains Escherichia coli ATCC 9637 and Staphylococcus aureus ATCC 29213, according to CLSI M7-A7 [41]

For the assay, individual bacterial colonies, pre-cultured overnight on MH agar (Oxoid, Italy), were checked for purity and suspended in $5.0 \mathrm{~mL}$ of sterile $\mathrm{NaCl} 0.85 \% \mathrm{w} / \mathrm{v}$ solution, until they reached a density corresponding to McFarland $1\left(3.0 \times 10^{8} \mathrm{CFU} / \mathrm{mL}\right)$ with an equivalent $\mathrm{OD}_{630}$ of $0.16-0.2$ (Bioteck Synergy HT, USA). The saline bacterial suspension was then diluted in MH broth to obtain a final concentration of about $5.0 \times 10^{5} \mathrm{CFU} / \mathrm{mL}$ in each well. The positive control was $\mathrm{MH}$ broth inoculated with the tested strain; the negative control was sterile MH broth. The 96-well plates were incubated as described by CLSI M100-S23 [43]. The absence of growth was confirmed by spreading $100 \mu \mathrm{L}$ from each well on MH agar in which bacterial growth seemed inhibited. The experiments were carried out twice in duplicate. 


\subsubsection{Cell lines and treatment culture and maintenance}

Human Umbilical Vein Endothelial Cells (HUVEC - CRL-1730 - from America Type Collection) were grown in tissue-culture Corning flasks (Sigma-Aldrich, St. Louis, MO) using Human Large Vessel Endothelial Cell Basal Medium (Medium 200) supplemented with Low Serum Growth Supplement (LSGS, composed of 2\% $\mathrm{v} / \mathrm{v}$ fetal bovine serum, $1 \mu \mathrm{g} / \mathrm{mL}$ hydrocortisone; $10 \mathrm{ng} / \mathrm{mL}$ human epidermal growth factor; $3 \mathrm{ng} / \mathrm{mL}$ basic fibroblast growth factor; $10 \mu \mathrm{g} / \mathrm{mL}$ heparin; Themo Fisher Scientific). The incubation was performed in a humidified atmosphere (95\% Air, $5 \% \mathrm{CO}_{2}$ ) at $37^{\circ} \mathrm{C}$ (Heraeus Hera Cell $150 \mathrm{C}$ incubator). The maintenance of the cells was performed according to the protocol described by Koob et al. (2014) [44]. Before the assay, the HUVEC cells at a density of $1 \times 10^{4}$ cells/well were seeded in 96-well cell culture plates (Cellstar, Sigma Aldrich, USA). For the treatment, the NPs pellets were diluted using Medium 200, added with cell lines and incubated for 24 hours at the cell growth conditions.

\subsubsection{Determination of bare and HA/pHA coated AgNPs and AuNPs toxicity}

To find a safe and non-toxic amount of bare and HA/ $p$ HA coated AgNPs and AuNPs the 3-(4, 5-dimethyl-2thiazolyl)-2,5-diphenyl-2-H-tetrazoliumbromide (MTT) assay was performed. The reaction was carried out by adding $0.5 \mathrm{mg} / \mathrm{mL}$ of MTT to each well. The absorbance was measured at $490 \mathrm{~nm}$ (Varioskan ${ }^{\circledR}$ Flash Spectral Scanning Multimode Readers, Thermo Scientific, USA) after 90 min when the reaction was stopped using 150 $\mu \mathrm{L}$ of DMSO for each well. The results were expressed as the percentage of viable cells referred to the concentration of each compound.

\subsubsection{Effects of $N P_{S}$ on collagenase activity}

The effect of tested nanoparticles on the enzymatic activity of collagenase was determined spectrophotometrically by quantifying the fragment produced by the enzymatic reaction against an external standard. The assay was performed by modifying the method described by Wunsch-Heidrich et al. (1963) [45, 46] Briefly, the enzymatic activity of collagenase was detected spectrophotometrically (absorbance of fragment at $320 \mathrm{~nm}$ ) by measuring the production of the glicil-L-prolil-D-arginine fragment (yellow) produced from the PZ-L-prolil-L-leucyl-glicil-L-prolil-D-arginine (PZ = 4-phenylazobenzyloxycarbonyl) synthetic 
substrate, after extraction with a solution of ethyl acetate acidified with citric acid. For the assay, a collagenase solution (ranging from 0.35 to $1.2 \mathrm{nkatal} / \mathrm{ml}$ ) was prepared using a buffer solution of $25 \mathrm{mM}$ TRIS- $\mathrm{HCl}$ and $10 \mathrm{mM} \mathrm{CaCl}_{2}$ (pH 7.1 adjusted using $\mathrm{HCl}$ ). The enzymatic reaction between collagenase and $1.23 \mathrm{mM}$ of substrate solution (PZ-L-prolil-L-leucyl-glicil-L-prolil-D-arginine) was carried out for 15 minutes at $37{ }^{\circ} \mathrm{C}$ in a water bath and two fragments, PZ-L-prolil-L-leucine and glicil-L-prolil-D-arginine, were obtained. The glicil-L-prolil-D-arginine (yellow) fragment was extracted using ethyl acetate solvent in the presence of citric acid. The organic solution was dehydrated using anhydrous $\mathrm{Na}_{2} \mathrm{SO}_{4}$ and the absorbance was determined spectrophotometrically (at $320 \mathrm{~nm}$, using a UV-1200 spectrometer). The substrate solution mixed with the buffer solution was used as the blank. The enzymatic activity was quantified as follows:

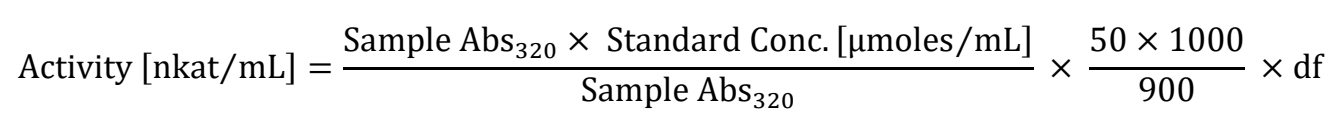

where standard concentration was $0.02 \mu$ moles $/ \mathrm{mL}, 50$ was the sample dilution factor, 1000 was the conversion factor from $\mu$ moles to nmoles, 900 was the number of seconds in 15 minutes, $d f$ was the dilution factor of collagenase to obtain a solution with a final activity ranging from 0.35 to $1.2 \mathrm{nkat} / \mathrm{mL}$.

The results are expressed as a relative percentage of collagenase activity $(\% \mathrm{~A})$ calculated as follows:

$$
\% \mathrm{~A}=\frac{\text { Activity of treated sample }}{\text { Activity of untreated sample }} \times 10
$$

\section{Results}

\subsection{Chemical and spectroscopical characterization of HA conjugate ( $\mathrm{pHA}$ )}

The ${ }^{1} \mathrm{H}-\mathrm{NMR}$ spectrum of Hyaluronic Acid-GHHPHGK-conjugate ( $\left.p \mathrm{HA}\right)$ is shown in Fig. 2 and displays the following characteristic signals: $8.68 \mathrm{ppm}(\mathrm{s}, 3 \mathrm{H}, \mathrm{H}-2)$ referred to the imidazole ring, 7.41, 7.35 and $7.31 \mathrm{ppm}$ (s, $3 \mathrm{H}$ totally, H-5) referred to the imidazole ring, 5.03 ppm (br s, $\mathrm{CH}$ of H), 4.6-4.5 ppm (br m, H-) referred to glucuronic acid and $\mathrm{H}-1$ referred to $\mathrm{N}$-acetylglucosamine, $4.31 \mathrm{ppm}$ (br s, CH of Lysine), $4.01 \mathrm{ppm}$ (br s, $\mathrm{CH}$ of P), 3.9-3.2 ppm (br m) H-2, H-3, H-4 and H-5 referred to glucuronic acid; H-2, H-3,H-4, H-5, H-6 referred to N-acetylglucosamine, $\underline{\mathrm{CH}_{2}}$ of G, $\underline{\mathrm{CH}_{2}} 5$ a and b of $\mathrm{P}, \underline{\mathrm{CH}_{2}}$ of $\mathrm{H}$ ), 3.13 ppm and $3.03 \mathrm{ppm}$ (br m, $\varepsilon$ 
$\underline{\mathrm{CH}_{2}}$ of Lysine), 2. 36 ppm (br m, CHa-3 of P), 2.11-1.95 ppm (br m, CHa-4 of P and $\mathrm{CH}_{3}$ referred to Nacetylglucosamine, 1.9-1.7 ppm (br m, CHb-3, CHb-4 of P and $\beta \underline{\mathrm{CH}_{2}}$ of Lysine), 1.49 ppm (br m, $\delta \underline{\mathrm{CH}_{2}}$ of K), 1.10 ppm (br m, $\gamma \underline{\mathrm{CH}_{2}}$ of Lysine) (Fig. 2). The amide bond formation between the free carboxylic group of HA residue and the amino group of the Lysine side chain was underlined by a resulting upfield shift $(\Delta \delta=$ $-0.10 \mathrm{ppm})$ of $\varepsilon$-methylene protons $(\delta=3.13 \mathrm{ppm})$ relative to the Lysine- $\mathrm{NH}_{2}$ moiety, as compared to the corresponding resonance of the non-conjugated peptide $(\delta=3.03 \mathrm{ppm})$.

The conjugate shows all the expected signals from the protons of peptide and hyaluronic acid units; all proton resonance signals were completely assigned. The amount of GHHPHGK peptide conjugated with HA results as being $\sim 15 \%$.

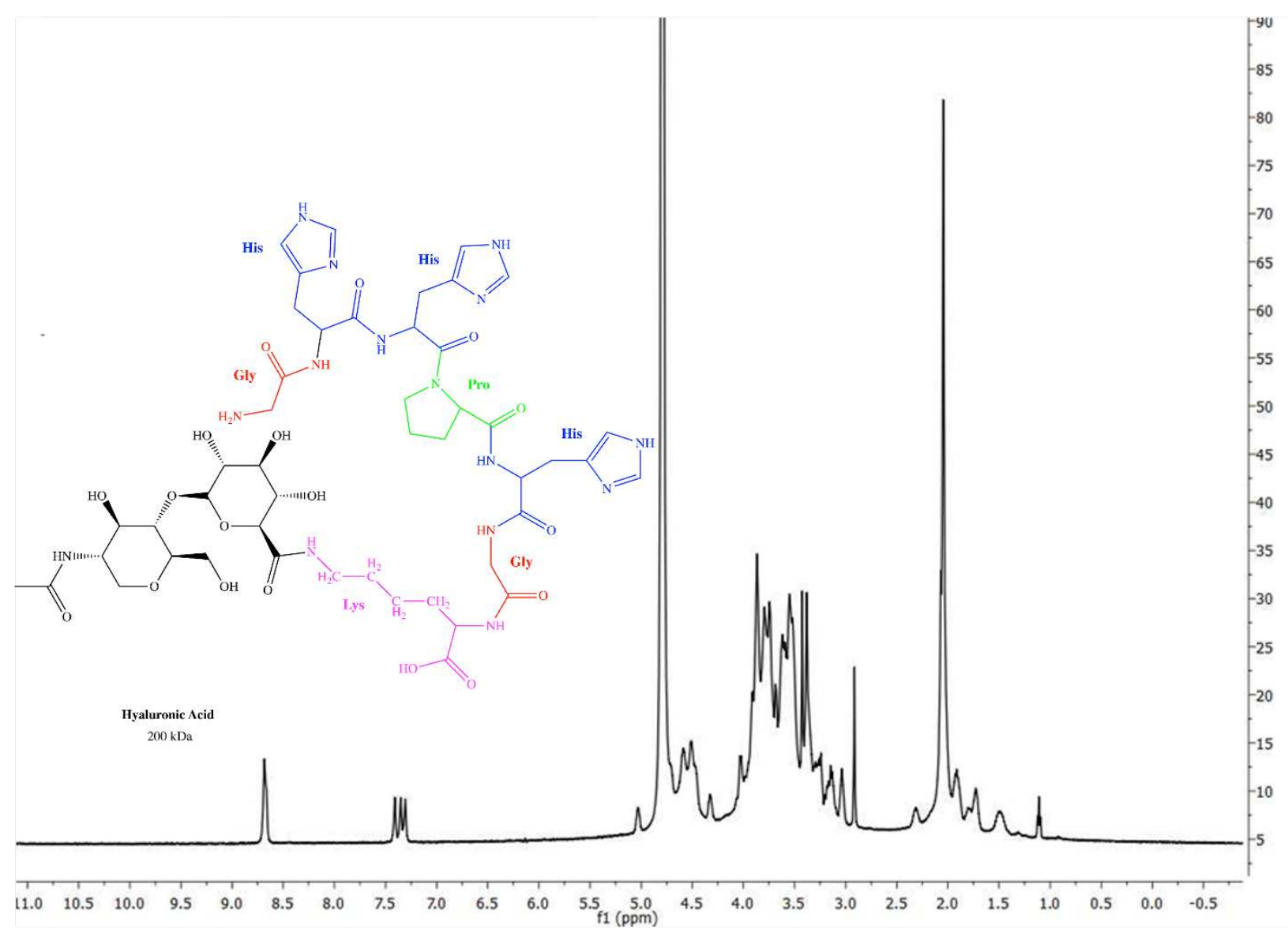

Figure 2. ${ }^{1} H-N M R$ spectrum of the Hyaluronic Acid-GHHPHGK conjugate ( $\left.p \mathrm{HA}\right)$ 


\subsection{Physicochemical characterization of bare and HA/pHA coated AgNPs and AuNPs}

\subsubsection{UV-Visible and Dynamic light scattering nanoparticle characterization}

Fig. 3 shows the absorbance in dependence of $\lambda$ for chemically ( $a$ and $a .1)$ and plasma ( $b$ and $b .1)$ synthetized AgNP, AuNP, HA-AgNP, $p \mathrm{HA}-\mathrm{AgNP}, \mathrm{HA}-\mathrm{AuNP}, p \mathrm{HA}-\mathrm{AuNP}$. The surface plasmon resonance is visible as a peak in the range between 395.3 and $397.5 \mathrm{~nm}$ for bare AgNP and between 535.0 and $546.0 \mathrm{~nm}$ for bare chemically synthetized AuNP ( $\left.{ }^{\mathrm{c}} \mathrm{AgNP},{ }^{\mathrm{c}} \mathrm{AuNP}\right)$ and those coated with HA and $p \mathrm{HA}\left(\mathrm{HA}-{ }^{\mathrm{c}} \mathrm{AgNP}, p \mathrm{HA}-\right.$ $\left.{ }^{\mathrm{c}} \mathrm{AuNP}\right)$. The AgNP peaks showed a decrease in $\mathrm{Abs}_{\max }$ compared to the bare ones when coated with HA and $p \mathrm{HA}$.

The surface plasmon resonance is visible as a peak in the range between 407.5 and $411.1 \mathrm{~nm}$ for bare AgNP and between 523 and $534 \mathrm{~nm}$ for bare AuNP prepared by plasma assisted synthesis ( $\left.{ }^{\mathrm{p}} \mathrm{AgNP},{ }^{\mathrm{p}} \mathrm{AuNP}\right)$ and those coated with $\mathrm{HA}$ and $p \mathrm{HA}\left(\mathrm{HA}-{ }^{\mathrm{p}} \mathrm{AgNP}, p \mathrm{HA}-{ }^{\mathrm{p}} \mathrm{AuNP}\right)$. All plasma prepared NPs were more polydispersed and red-shifted (Fig. 3). The red-shift between chemically and plasma synthetized HA-AgNP $\left(\Delta \lambda_{\max }\right.$ of 2.2 and 3.6 $\mathrm{nm}$, respectively) and $p \mathrm{HA}-\mathrm{AgNP}\left(\Delta \lambda_{\max }\right.$ of 1.8 and $1.2 \mathrm{~nm}$, respectively) was noteworthy. This effect could be due to the extra interactions between the histidine group of the peptide and the $\mathrm{Ag}^{+}$ions during seed formation, resulting in a thicker shell for $p \mathrm{HA}$ with respect to HA. The FWHM (Full Width at Half Maximum) of the plasmon peaks ranged between 63 and 72 for ${ }^{\mathrm{c}} \mathrm{AgNPs}$ and from 87 and 99 for plasma prepared ones; the larger size of the optical diameters was due to the HA and $p \mathrm{HA}$ shell around the metallic core. The peak of bare ${ }^{\mathrm{p}} \mathrm{AgNPs}$ was damped with respect to those obtained by chemical synthesis. The peaks of HA- ${ }^{\mathrm{C}} \mathrm{AgNP}$, $p H A-{ }^{c} A g N P$ were almost overlapped. The ${ }^{\mathrm{c}} \mathrm{AgNP}$ shows a linear variation of the $\lambda_{\max }$ as a function of HA presence following a different trend compared to ${ }^{\mathrm{p}} \mathrm{AgNP}$ which produced a high redshift when HA is conjugated with antiangiogenic peptide GHHPHGK $(p \mathrm{HA})$.

The Abs max peak of AuNPs was right shifted with respect to those of AgNPs for both chemically and plasma synthetized ones. The Abs max peak of ${ }^{\mathrm{p}} \mathrm{AuNPs}$ was left shifted with respect to the chemically synthetized ones. For both syntheses it is possible to observe a red shift of the $\lambda_{\max }$ of HA-AuNP compared to AuNP, relative to the increase in NP optical diameter (Fig. 3). This red shift is more intense for $p$ HA-AuNP (1.1 nm for both chemically and plasma synthetized), a linear variation of the $\lambda_{\max }$ was observed for ${ }^{\mathrm{c} A u N P}$ with respect to plasma synthetized ones, as a function of the HA presence. The broad plasmon band for $p \mathrm{HA}--^{\mathrm{c}} \mathrm{AuNP}$ is evidence of the presence of several populations of various sizes. On the contrary, ${ }^{\mathrm{p}}$ AuNP and HA- ${ }^{\mathrm{p}}$ AuNP 
exhibited a smaller size than the ${ }^{\mathrm{p}} \mathrm{AgNPs}$. The $p \mathrm{HA}-{ }^{\mathrm{p}} \mathrm{AuNP}$ plasmon band points to the formation of a monodisperse solution of larger NPs. These differences could be due to the different charge of the respective metal precursors salts, monovalent silver and trivalent gold. The hydrodynamic diameter is higher than the optical size except for glucose-capped ${ }^{\mathrm{c}} \mathrm{AuNP}$ and $\mathrm{HA}-{ }^{\mathrm{c}} \mathrm{AuNP}$ which showed quite similar values. The glucose used as reducing agent for synthesis of ${ }^{\mathrm{c}} \mathrm{AuNP}$ could contribute to forming a dense and rigid shell around the nanoparticles which roughly corresponds to the hydration shell around the NPs.
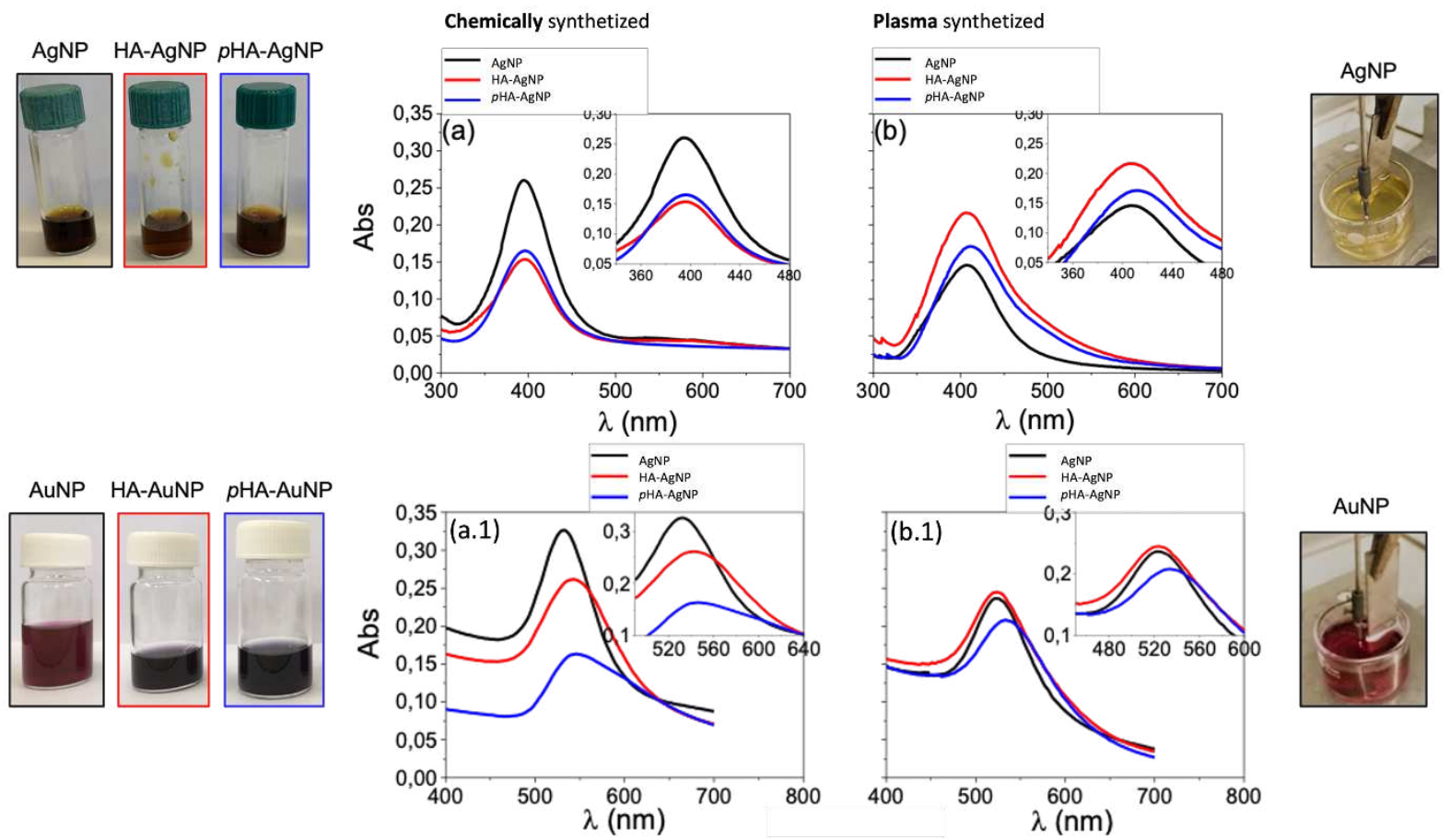


\begin{tabular}{|c|c|c|c|c|c|c|c|c|c|c|c|c|}
\hline \multirow[b]{2}{*}{ Parameters } & \multicolumn{6}{|c|}{ Chemical synthesis } & \multicolumn{6}{|c|}{ Plasma synthesis } \\
\hline & $\frac{0}{\mathrm{z}}$ & $\begin{array}{l}\frac{0}{2} \\
\frac{9}{1} \\
\frac{1}{1}\end{array}$ & $\begin{array}{l}\frac{0}{2} \\
\frac{1}{\alpha} \\
\frac{1}{1} \\
\frac{1}{2}\end{array}$ & $\underset{z}{\frac{2}{z}}$ & $\begin{array}{l}\frac{0}{2} \\
\text { 妾 } \\
\text { 主 }\end{array}$ & $\begin{array}{l}\frac{0}{2} \\
\frac{1}{1} \\
\frac{1}{1} \\
\frac{1}{2}\end{array}$ & $\frac{0}{z}$ & $\begin{array}{l}\frac{0}{2} \\
\frac{8}{8} \\
\text { 主 }\end{array}$ & $\begin{array}{l}\frac{0}{z} \\
0 \\
\frac{1}{1} \\
\frac{1}{2} \\
\frac{1}{2}\end{array}$ & $\underset{z}{\frac{1}{z}}$ & $\begin{array}{l}\frac{0}{2} \\
\frac{3}{\alpha} \\
\text { 主 }\end{array}$ & $\begin{array}{l}\frac{0}{z} \\
\frac{1}{d} \\
\frac{1}{1} \\
\frac{1}{2}\end{array}$ \\
\hline$\lambda_{\max }(\mathrm{nm})$ & 395.3 & 397.1 & 397.5 & 535.0 & 543.0 & 546.0 & 407.5 & 408.7 & 411.1 & 523.0 & 524.0 & 534.0 \\
\hline $\mathrm{Abs}_{\max }$ & 0.261 & 0.154 & 0.163 & 0.327 & 0.262 & 0.162 & 0.144 & 0.217 & 0.171 & 0.238 & 0.246 & 0.208 \\
\hline FWHM & 66 & 63 & 72 & 53 & 70 & 101 & 87 & 89 & 99 & 51 & 58 & 59 \\
\hline$d_{0}(n m)$ & 12 & 14 & 14 & 55 & 76 & 84 & 33 & 35 & 38 & 22 & 24 & 52 \\
\hline$\Delta \mathrm{d}_{0} \%$ & - & 14 & 14 & - & 28 & 38 & - & 6 & 13 & - & 8 & 58 \\
\hline$[\mathrm{nM}] \times 10^{-9}$ & 1.58 & 1.08 & 0.93 & 0.03 & 0.03 & 0.01 & 0.07 & 0.09 & 0.06 & 0.83 & 0.58 & 0.09 \\
\hline$[\mathrm{NP} / \mathrm{mL}]$ & $\begin{array}{l}\stackrel{\circ}{\circ} \\
\stackrel{0}{\hat{0}} \\
\stackrel{0}{r}\end{array}$ & 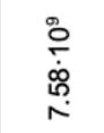 & 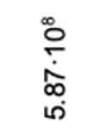 & 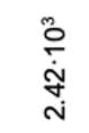 & $\begin{array}{l}\stackrel{0}{\circ} \\
\stackrel{\tilde{\tilde{D}}}{0} \\
\stackrel{0}{0}\end{array}$ & 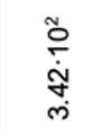 & $\begin{array}{l}\stackrel{0}{\circ} \\
\dot{\phi} \\
\dot{\oplus}\end{array}$ & $\begin{array}{l}\grave{0} \\
\dot{8} \\
\dot{+}\end{array}$ & $\begin{array}{l}\stackrel{\circ}{\dot{\delta}} \\
\stackrel{\infty}{\circ}\end{array}$ & 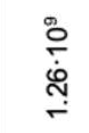 & 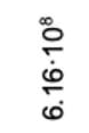 & 홇 \\
\hline
\end{tabular}

\subsubsection{ATR-FTIR nanoparticle characterization}

The ATR-FTIR spectra of chemically synthetized HA-AgNP (HA- $\left.{ }^{\mathrm{c}} \mathrm{AgNP}\right)$ are $3311 \mathrm{~cm}^{-1}$ (-OH stretching; NH stretching), $2923 \mathrm{~cm}^{-1}$ (- $\mathrm{CH}_{2}$ stretching), $1605 \mathrm{~cm}^{-1}$ (-C=O stretching, $-\mathrm{NH}$ bending), $1408 \mathrm{~cm}^{-1}\left(-\mathrm{CH}_{2}\right.$ bending), $1027 \mathrm{~cm}^{-1}$ (-C-O-C- stretching). The variations in - $\mathrm{OH} /-\mathrm{NH}$ and $-\mathrm{CH}_{2}$ stretching with respect to the corresponding HA indicate the different electronic interaction of this group of HA with the metal ${ }^{\mathrm{c}} \mathrm{AgNPs}$ (Fig. 4).

When the HA-AgNP is synthetized by plasma (HA-PAgNP) the IR spectra values are: $3460 \mathrm{~cm}^{-1}(-\mathrm{OH}$ stretching; -NH stretching), $3289 \mathrm{~cm}^{-1}$ (- $\mathrm{CH}_{2}$ stretching), $1604 \mathrm{~cm}^{-1}$ (-C=O stretching, -NH bending), $1405 \mathrm{~cm}^{-}$ ${ }^{1}$ (- $\mathrm{CH}_{2}$ bending), $1095 \mathrm{~cm}^{-1}$ (-C-O-C- stretching). (Fig. 4). There a noteworthy variation in $-\mathrm{CH}_{2}$ stretching of HA- ${ }^{\mathrm{p}} \mathrm{AgNP}$, in $-\mathrm{C}=\mathrm{O}$ stretching, $-\mathrm{NH}$ bending and in $-\mathrm{C}-\mathrm{O}-\mathrm{C}-$ stretching for HA- ${ }^{\mathrm{p}} \mathrm{AuNP}$ with respect to the corresponding signal for HA. These results could be due to the different interactions between NP plasma synthetized with the carboxylate (-COO-) and amide (-NH) groups of HA (Fig.4).

The IR values for HA- ${ }^{-} \mathrm{AuNP}$ are: $3277 \mathrm{~cm}^{-1}$ (-OH stretching; -NH stretching), $2905 \mathrm{~cm}^{-1}\left(-\mathrm{CH}_{2}\right.$ stretching), $1605 \mathrm{~cm}^{-1}$ (-C=O stretching, -NH bending), $1409 \mathrm{~cm}^{-1}$ (- $\mathrm{CH}_{2}$ bending), $1027 \mathrm{~cm}^{-1}$ (-C-O-C- stretching) (Fig. 4). The IR values for HA- ${ }^{\mathrm{P}} \mathrm{AuNP}$ are: $3459 \mathrm{~cm}^{-1}$ (-OH stretching; -NH stretching), $2943 \mathrm{~cm}^{-1}$ (- $\mathrm{CH}_{2}$ stretching), 
$1669 \mathrm{~cm}^{-1}$ (-C=O stretching, -NH bending), $1467 \mathrm{~cm}^{-1}$ (- $\mathrm{CH}_{2}$ bending), $1156 \mathrm{~cm}^{-1}$ (-C-O-C- stretching) (Fig.

4).

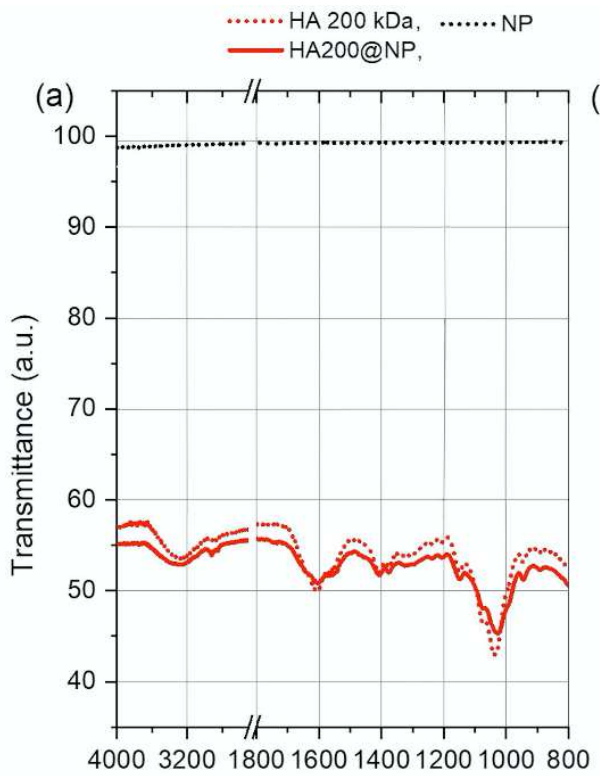

(b)

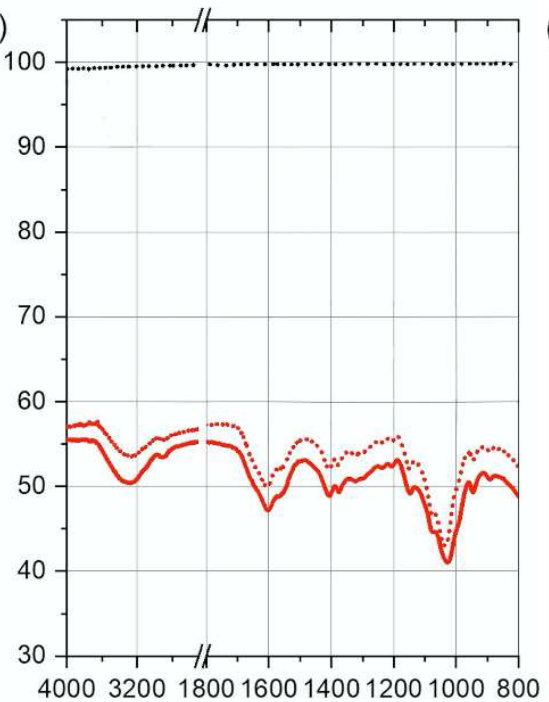

(c)

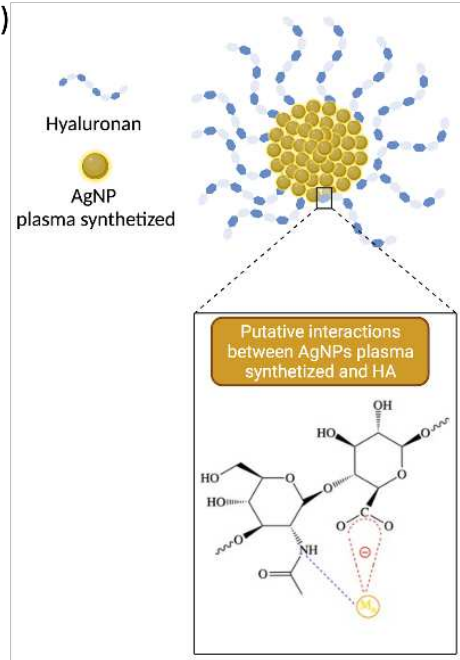

Figure 4. IR/ATR spectra of chemically synthetized NPs coated with HA (200 kDa). (a) AgNPs and (b) AuNPs. (c) Schematic illustration of primary interaction between synthetized AgNP plasma and hyaluronan.

\begin{tabular}{|c|c|c|c|c|c|c|c|c|c|c|}
\hline \multirow[b]{2}{*}{ Parameters } & \multicolumn{5}{|c|}{ Chemical synthesis } & \multicolumn{5}{|c|}{ Plasma synthesis } \\
\hline & 至 & $\frac{0}{z}$ & 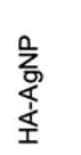 & $\sum_{z}^{0}$ & $\begin{array}{l}\text { 足 } \\
\text { 妾 } \\
\text { 咅 }\end{array}$ & 조 & $\frac{n}{z}$ & 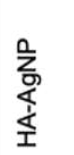 & $\underset{\frac{1}{2}}{\frac{0}{2}}$ & 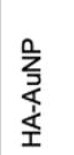 \\
\hline$-\mathrm{OH} /-\mathrm{NH}$ stretching & 3279 & - & 3311 & - & 3277 & 3414 & - & 3460 & - & 3459 \\
\hline$-\mathrm{CH}_{2}$ stretching & 2890 & - & 2923 & - & 2905 & 2895 & - & 3289 & - & 2943 \\
\hline $\begin{array}{l}-\mathrm{C}=\mathrm{O} \text { stretching } \\
-\mathrm{NH} \text { bending }\end{array}$ & 1603 & - & 1605 & - & 1605 & 1556 & - & 1604 & 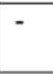 & 1696 \\
\hline$-\mathrm{CH}_{2}$ bending & 1399 & - & 1408 & - & 1409 & 1372 & - & 1405 & - & 1467 \\
\hline C-O-C stretching & 1033 & - & 1027 & - & 1027 & 1011 & - & 1095 & - & 1156 \\
\hline
\end{tabular}

Table 2. Peak position $\left(\mathrm{cm}^{-1}\right)$ of the characteristic transmittance spectra of the hyaluronic acid coating chemically and plasma synthetized NPS

\subsubsection{Atomic Force Microscopy nanoparticle characterization}

The atomic force microscopy (AFM) images of HA ( $200 \mathrm{kDa})$ show a layer of macromolecules $<0.5 \mathrm{~nm}$ thick, indicating an aggregation force between chains, as well as rather strong hydrophilic interactions between the mica substrate and HA, typical of the low molecular weight. The stiffness of the HA molecules is apparent and 
is due to dehydration (Fig. 5 a-c). HA-AgNP and HA-AuNP show the HA monolayer around the core of aggregated NPs, especially for HA-AuNPs with respect to HA-AgNP. The dimensions of the height images were $25 \mathrm{~nm}$ and $60 \mathrm{~nm}$ for HA-AgNPs obtained by chemical synthesis and $27 \mathrm{~nm}$ and $30 \mathrm{~nm}$ for plasma synthetized ones, with different microscopic characteristics typical of globular hybrid-polymer metal nanoparticle systems (Fig. 5).

\subsubsection{Diameter size determination by transmission electron microscope (TEM)}

The chemically and plasma synthetized AgNPs and AuNPs showed two different aging trends: AgNP aging (with and without HA) shows $\lambda_{\max }$ red-shift of the plasmonic peaks (in all cases the $\Delta \lambda_{\max }<1 \mathrm{~nm}$ ) The synthetized AuNP plasma showed a $\Delta \lambda_{\max }$ decrease and a $\Delta \lambda_{\max }<1 \mathrm{~nm}$ in all cases, except for HA-AuNP which shows a $\Delta \lambda_{\max }=1.3 \mathrm{~nm}$, at an aging time of 15 days. The AuNP suspension contained aggregates of various sizes at the initial growth stage. The TEM images (Fig. 5) show a size decrease for the HA-AgNP plasma synthetized after three days of aging and a tight size range $(20-30 \mathrm{~nm})$ for $46 \%$ of the NPs; $20 \%$ showed a size ranging between 10 and $20 \mathrm{~nm}$, while $0 \%$ of NP showed a range between 0 and $10 \mathrm{~nm}$. 

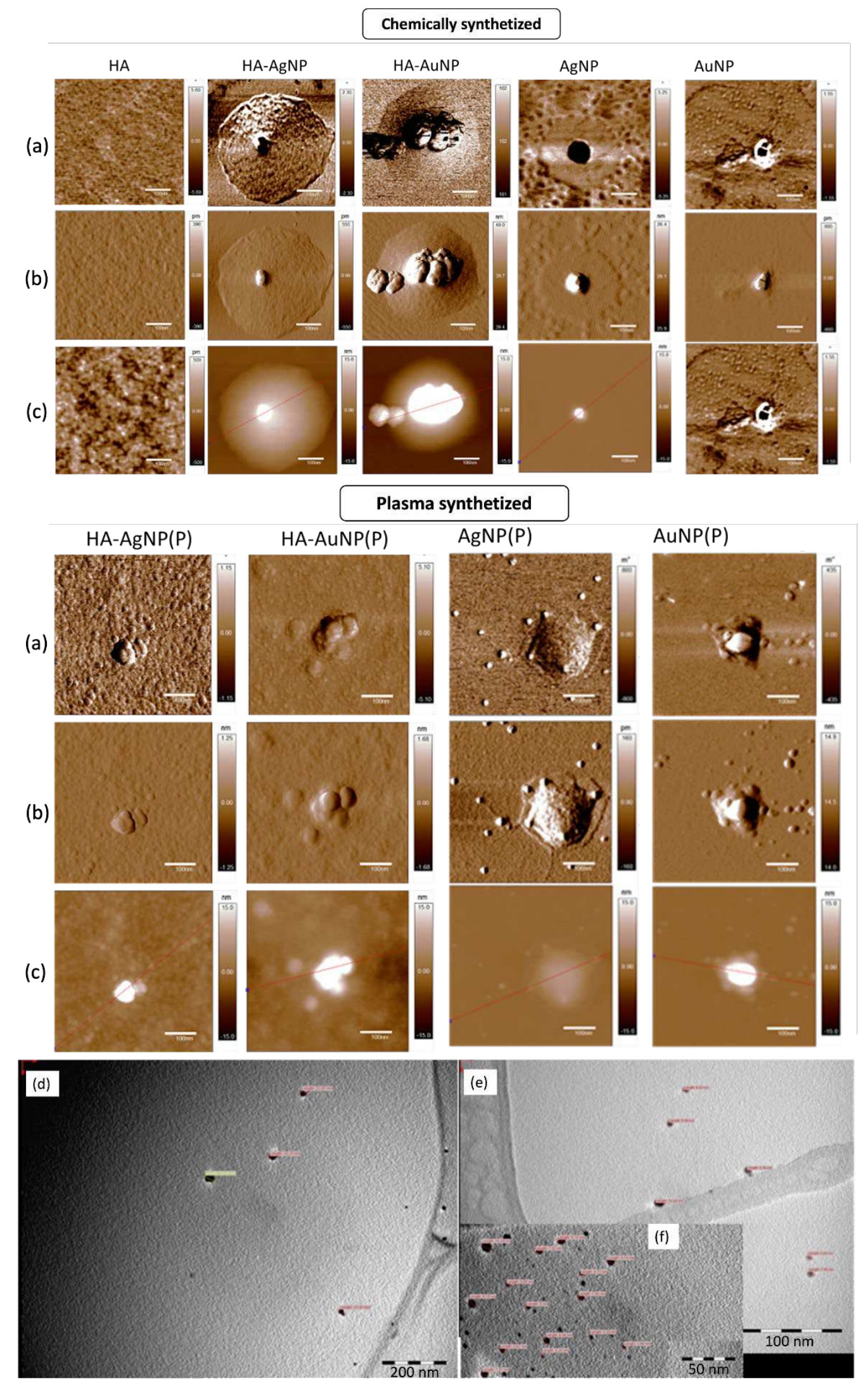

Figure 5. Microscopy characterization of NPs. AFM images of chemically and plasma synthetized HA, HA-AgNP, HAAuNP, AgNP, AuNP. (a) Phase, (b) amplitude; (c) height images. TEM image of plasma synthetized (d) HA-AuNP, (e) and (f) HA-AuNPs aged 3 days. 


\subsection{Biological properties}

\subsubsection{Antibacterial activity}

The MIC values of all the tested NPs were lower than those of chloramphenicol (CHL); NPs were more active against Escherichia coli ATCC 9637 and no significant differences were observed for HA and $p \mathrm{HA}$ coated NPs. AuNP was less toxic with respect to AgNP.

With the agar diffusion method, the antibacterial activity of NPs was shown to be lower with respect to that observed using the broth microdilution method and AuNPs did not show any inhibitory activity. These results could be due to interactions between NPs and the agar mesh. All chemically synthetized AgNPs $\left({ }^{\circ} \mathrm{AgNPs}, \mathrm{HA}-\right.$ ${ }^{\mathrm{c}} \mathrm{AgNPs}, p \mathrm{HA}-{ }^{\mathrm{c}} \mathrm{AgNPs}$ ) showed a clear inhibition zone for both tested strains (Fig. 6 A). Plasma synthetized AgNPs $\left({ }^{\mathrm{p}} \mathrm{AgNPs}\right)$ did not show any inhibitory activity. However, when coated with HA and $p$ HA (HA- ${ }^{\mathrm{p}} \mathrm{AgNPs}$, $\left.p \mathrm{HA}^{\mathrm{p}} \mathrm{AgNPs}\right), p \mathrm{HA}-{ }^{\mathrm{p}} \mathrm{AgNP}$ showed a very strong $(\mathrm{ZOI}=18.0 \mathrm{~mm})$ inhibitory activity against $E$. coli ATCC 9637 and a strong $(\mathrm{ZOI}=15.0 \mathrm{~mm})$ inhibitory activity against $S$. aureus ATCC 29213 . This activity is six-fold

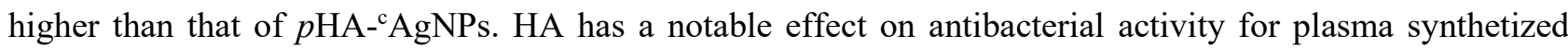
nanoparticles. The HA- ${ }^{\mathrm{p}} \mathrm{AgNPs}$ showed a strong $(\mathrm{ZOI}=15.0 \mathrm{~mm})$ inhibitory activity against $E$. coli ATCC 9637 and a good $(\mathrm{ZOI}=13.0 \mathrm{~mm})$ inhibitory activity against $S$. aureus ATCC 29213 . This activity is two-fold higher than those of $p \mathrm{HA}-{ }^{\mathrm{c}} \mathrm{AgNPs}$.

Using the broth microdilution method, NPs were shown to be more active against E. coli ATCC 9637, confirming the results obtained using the agar diffusion method (Fig. 6 A.1). The highest inhibitory activity was shown towards E. coli ATCC 9637 by $p H A-{ }^{c} A u N P(\mathrm{MIC}=0.24 \mathrm{nM})$ followed by HA- ${ }^{\mathrm{c}} \mathrm{AuNP}(\mathrm{MIC}=$ $0.55 \mathrm{nM}),{ }^{\mathrm{c}} \mathrm{AuNP}(\mathrm{MIC}=0.58 \mathrm{nM})$ and $p \mathrm{HA}-{ }^{\mathrm{p}} \mathrm{AgNP}(\mathrm{MIC}=0.90 \mathrm{nM})$. The ${ }^{\mathrm{c}} \mathrm{AuNP}, \mathrm{HA}-{ }^{\mathrm{c}} \mathrm{AuNP}$ and $p \mathrm{HA}-$ ${ }^{\mathrm{c} A u N P}$ showed the same MIC values against $S$. aureus ATCC 29213. AgNPs, HA- ${ }^{\mathrm{p}}$ AgNPs and $p$ HA- ${ }^{\mathrm{p}}$ AgNPs did not show any activity in broth solution. These results are dependent on HA molecular weight (MW); in fact, using a high MW, HA was shown to be less active (data not shown). Moreover, the surface characteristics of ${ }^{\mathrm{P} P P s}$ improve their antibacterial activity, particularly against Gram-negative strain, which have a thin peptidoglycan layer and an outer lipid membrane in their cell walls 


\subsubsection{Cytotoxic activity on Human Umbilical Vein Endothelial Cells (HUVEC)}

The results of the MTT (tetrazolium salt (3-(4,5-dimethylthiazol-2-yl)-2,5-diphenyltetrazolium bromide) assay on Human Umbilical Vein Endothelial Cells (HUVEC) showed that cell viability is a function of NPs and of the final yield depending on the method used for the synthesis (Fig.6 B). The NPs obtained by the chemical method showed a higher toxicity with respect to those obtained by plasma technology (cell viability $\geq 69 \%$ and $\geq 83 \%$, respectively). The HA and HA conjugated with GHHPHGK ( $p \mathrm{HA})$ at the highest tested concentration increased the cytotoxicity of chemically synthetized AgNP ( $80 \%$ and $69.11 \% v s 84.47 \%)$. The bare and $p$ HA coated NPs reduced HUVEC viability by $\sim 20 \%(p<0.01)$. The plasma synthetized NPs did not show significant cytotoxicity with respect to the untreated control.

\subsubsection{Effect on collagenase activity}

After treatment with AgNPs, collagenase activity was reduced by $20 \%$ (Fig. 6 C). In the presence of plasma synthetized AgNPs, collagenase activity is higher respect to what determined in presence of chemically synthetized NPs (91\% vs 84,57\%). Nevertheless, collagenase activity stays at high levels when chemically synthetized AgNPs are coated with HA (HA-AgNP). 


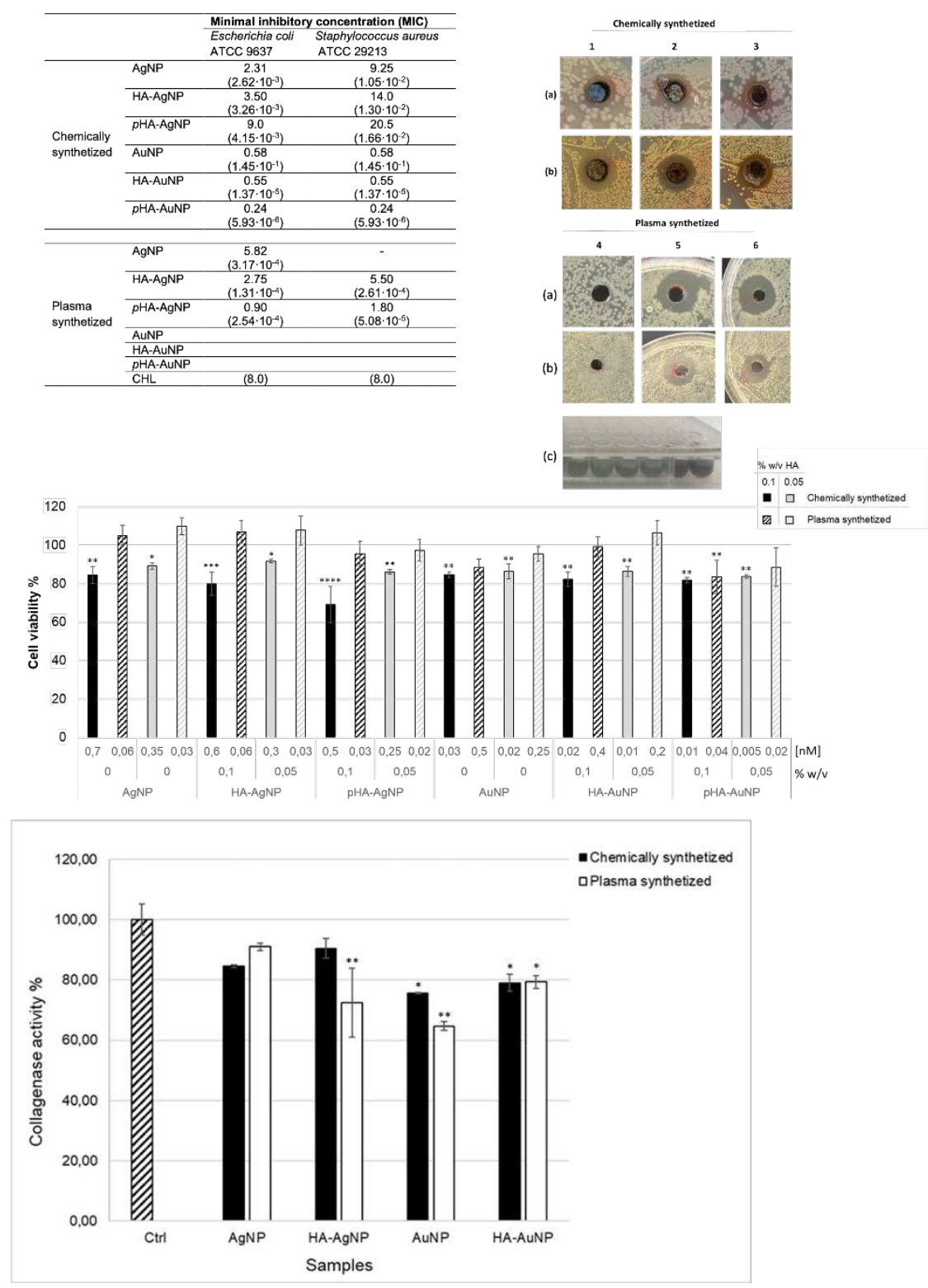

Figure 6. Biological properties of chemically and plasma synthetized NPs. (A) Clear inhibition zones of chemically and plasma synthetized NPs. (a) Mueller Hinton (MH) agar plate spread with Escherichia coli ATCC 9637. (b) MH agar plate spread with Staphylococcus aureus ATCC 29213. (a.1 and b.1) Treatment with chemically synthetized AgNP (9.25 $\left.n M=1.05 \cdot 10^{-2} \mu \mathrm{g} / \mathrm{mL}\right) ;\left(a .2\right.$ and b.2) treatment with chemically synthetized HA-AgNP $\left(14.0 \mathrm{nM}=1.30 \cdot 10^{-2} \mu \mathrm{g} / \mathrm{mL}\right) ;(a .3$ and $b .3)$ treatment with chemically synthetized $p H A-A g N P\left(20.5 \mathrm{nM}=1.66 \cdot 10^{-2} \mu \mathrm{g} / \mathrm{mL}\right) ;($ a.4 and b.4) treatment with plasma synthetized AgNP (5.82 $\left.\mathrm{nM}=3.17 \cdot 10^{-4} \mu \mathrm{g} / \mathrm{mL}\right) ;($ a.5 and b.5) treatment with plasma synthetized HA-AgNP (5.51 $\left.n M=2.61 \cdot 10^{-4} \mu \mathrm{g} / \mathrm{mL}\right)$; (a.6 and b.6) treatment with plasma synthetized $\mathrm{pHA}-\mathrm{AgNP}\left(3.60 \mathrm{nM}=1.02 \cdot 10^{-4} \mu \mathrm{g} / \mathrm{mL}\right) .(\mathrm{A} .1)$ MIC values of chemically and plasma synthetized NPs against E. coli ATCC 9637 and S. aureus ATCC 29213, expressed in $n M$ and $\mu \mathrm{g} / \mathrm{m}$, shown in round brackets. (c) Microplate, after $1 \mathrm{~h}$ of incubation the wells contain plasma synthetized AuNP, HA-AuNP and pHA-AuNP. A turbidity probably due to bacterial cell destruction is visible. (B) Cell viability percentage of Human Umbilical Vein Endothelial Cells (HUVEC) after 24 h of incubation with NP, HA-NP and pHA-NP at different concentrations. The black and grey full bars are for chemically synthetized NPs; the bars with black and grey diagonal stripes are for plasma synthetized NPs. The AgNP, HA-AgNP, pHA-AgNP, AuNP, HA-AuNP, pHA-AuNP at highest tested concentration are black colored, the lowest tested concentrations for each NPs are grey colored. The untreated cells showed $100 \%$ viability. The results are expressed as the mean $\pm S D$ of triplicate experiments and normalized to the values for the untreated control. The statistical significance with respect to the untreated control calculated by one-way analysis of variance was: $*=p \leq 0.05 ; * *=p \leq 0.01 ; * * *=p \leq 0.001 ; * * * *=p \leq 0.0001$. (C) Percentage of collagenase activity after treatment with chemically (black solid bars) and plasma (empty bars) synthetized nanoparticles compared with collagenase alone (ctrl). The significant differences in collagenase activity compared to the control are indicated as follows: $*=p<0.05 ; * *=p<0.01$. 


\section{Conclusion}

The results collected in this study lead to the consideration of cold plasma technology as an efficient method for the synthesis of gold and silver nanoparticles, which is also applicable in the industrial field. The nanoparticles obtained were stable and the physisorption with Hyaluronic Acid contributed to modulating their aggregation kinetic and stabilizing their biological properties, especially against Gram-negative bacteria, maintaining their safety profile when tested on HUVEC cells. Our research on the synthesis of nanoparticles composed of noble metals provides promising bioactive compounds with reduced side effects, using substances that could constitute a reference for the fight against bacterial resistance, the elusive mechanisms of onco-related pathologies and other ailments where these systems have been shown to be applicable.

\section{Acknowledgements}

The authors acknowledge to the European Union (M-ERA.NET 2 Cofound H2020 Joint transnational Call 2016 DM 593 MUR project n. SmartHyCAR 4274. 


\section{Reference}

[1] Shimmin, R. G.; Schoch, A. B.; Braun, P. V., Polymer Size and Concentration Effects on the Size of Gold Nanoparticles Capped by Polymeric Thiols. Langmuir 2004, 20 (13), 5613-5620.

[2] Thanh NT, Maclean N, Mahiddine S. Mechanisms of nucleation and growth of nanoparticles in solution. Chem Rev. 2014 Aug 13;114(15):7610-30. doi: 10.1021/cr400544s. Epub 2014 Jul 8. PMID: 25003956.

[3] Di Pietro PD, Strano G, Zuccarello L, Satriano C. Gold and Silver Nanoparticles for Applications in Theranostics. Curr Top Med Chem. 2016;16(27):3069-3102. doi: 10.2174/1568026616666160715163346. PMID: 27426869.

[4] Balu SS, Harke, Chittaranjan B, Sanjay H. Synthesis of silver nanoparticles by chemical reduction and their antimicrobial activity. IJERT. 2012; 1: 1-5.

[5] Chudobova, D.; Nejdl, L.; Gumulec, J.; Krystofova, O.; Rodrigo, M.; Kynicky, J.; Ruttkay-Nedecky, B.; Kopel, P.; Babula, P.; Adam, V.; Kizek, R., Complexes of Silver(I) Ions and Silver Phosphate Nanoparticles with Hyaluronic Acid and/or Chitosan as Promising Antimicrobial Agents for Vascular Grafts. International Journal of Molecular Sciences 2013, 14 (7), 13592-13614.

[6] Agnihotri S, Mukherji S, Mukherji S. Size-controlled silver nanoparticles synthesized over the range 5-100 nm using the same protocol and their antibacterial efficacy.RSC Adv. 2014; 4: 3974.

[7] Shakeel Ahmed, Saifullah, Mudasir Ahmad, Babu Lal Swami, Saiqa Ikram, Green synthesis of silver nanoparticles using Azadirachta indica aqueous leaf extract, Journal of Radiation Research and Applied Sciences, Volume 9, Issue 1, 2016, Pages 1-7,

[8] Ferreres G, Pérez-Rafael S, Torrent-Burgués J, Tzanov T. Hyaluronic Acid Derivative Molecular Weight-Dependent Synthesis and Antimicrobial Effect of Hybrid Silver Nanoparticles. Int J Mol Sci. 2021 Dec 14;22(24):13428. doi: 10.3390/ijms222413428. PMID: 34948227; PMCID: PMC8707691.

[9] Burdușel, A.-C.; Gherasim, O.; Grumezescu, A. M.; Mogoantă, L.; Ficai, A.; Andronescu, E., Biomedical Applications of Silver Nanoparticles: An Up-to-Date Overview. Nanomaterials 2018, 8 (9).

[10] Padalia, H., Moteriya, P., \& Chanda, S. (2014). Green synthesis of 58 silver nanoparticles from marigold flower and its synergistic 59 antimicrobial potential. Arabian Journal of Chemistry. http:// 60 dx.doi.org/10.1016/j.arabjc.2014.11.015.

[11]B. Ajitha, Y. Ashok Kumar Reddy, P. Sreedhara Reddy, Green synthesis and characterization of silver nanoparticles using Lantana camara leaf extract, Materials Science and Engineering: C, Volume 49, 2015,

[12] Sadeghi, A.; Toghyani, M.; Gheisari, A., 2015. Effect of various fiber types and choice feeding of fiber on performance, gut development, humoral immunity, and fiber preference in broiler chicks. Poult. Sci., 94 (11): $2734-$ 2743

[13] Sre, PRR, Reka, M, Poovazhagi, R. Antibacterial and cytotoxic effect of biologically synthesized silver nanoparticles using aqueous root extract of Erythrina indica lam. Spectrochim Acta Part A 2015; 135: 1137-1144.

[14] Gannimani, R., Perumal, A., Krishna, S.B., Sershen, Muthusamy, K., Mishra, A., Govender, P (2014) Synthesis and antibacterial activity of silver and gold nanoparticles produced using aqueous seed extract of protorhus longifolia as a reducing agent. Digest Journal of Nanomaterials and Biostructures 9(4) pp 1669-1679

[15] Baalousha M, Lead JR. Nanoparticle dispersity in toxicology. Nat Nanotechnol. 2013 May;8(5):308-9. doi: 10.1038/nnano.2013.78. PMID: 23648733.

[16] Jo, M.-R.; Bae, S.-H.; Go, M.-R.; Kim, H.-J.; Hwang, Y.-G.; Choi, S.-J., Toxicity and Biokinetics of Colloidal Gold Nanoparticles. Nanomaterials 2015, 5 (2), 835-850.

[17] Guo, H.; Zhang, J.; Boudreau, M.; Meng, J.; Yin, J.-j.; Liu, J.; Xu, H., Intravenous administration of silver nanoparticles causes organ toxicity through intracellular ROS-related loss of inter-endothelial junction. Particle and Fibre Toxicology 2016, 13 (1).

[18] Tang, J.; Lu, X.; Chen, B.; Cai, E.; Liu, W.; Jiang, J.; Chen, F.; Shan, X.; Zhang, H. J. T. J. o. t. s., Mechanisms of silver nanoparticles-induced cytotoxicity and apoptosis in rat tracheal epithelial cells. 2019, 44 (3), 155-165.

[19] Demaude, A., Inturri, R., Satriano, C., Leroy, P., Reniers, F. Tuning the wicking and wettability properties of PET textiles by DBD or a remote atmospheric RF torch: A comparison Plasma Processes and Polymersthis link is disabled, 2021, 18(6), 2100005

[20] Jaiswal, S., Aguirre, E.M. \& Prakash, G.V. A KHz frequency cold atmospheric pressure argon plasma jet for the emission of O(1S) auroral lines in ambient air. Sci Rep 11, 1893 (2021). https://doi.org/10.1038/s41598-021-81488$\mathrm{X}$ 
[21] Naz, M.Y., Shukrullah, S., Rehman, S.U. et al. Optical characterization of non-thermal plasma jet energy carriers for effective catalytic processing of industrial wastewaters. Sci Rep 11, 2896 (2021). https://doi.org/10.1038/s41598021-82019-4

[22] Sohn HY, Murali A. Plasma Synthesis of Advanced Metal Oxide Nanoparticles and Their Applications as Transparent Conducting Oxide Thin Films. Molecules. 2021 Mar 7;26(5):1456. doi: 10.3390/molecules26051456. PMID: 33800111; PMCID: PMC7962204.

[23] Sharmin N, Pang C, Sone I, Walsh JL, Fernández CG, Sivertsvik M, Fernández EN. Synthesis of Sodium AlginateSilver Nanocomposites Using Plasma Activated Water and Cold Atmospheric Plasma Treatment. Nanomaterials (Basel). 2021 Sep 5;11(9):2306. doi: 10.3390/nano11092306. PMID: 34578622; PMCID: PMC8472623.

[24] New derivatives obtained from hyaluronic acid and carnosine. (filing date: 11.06.2020; application number: 102020000014017).

[25] EP 3174555 B1 Derivatives obtained from hyaluronic acid and carnosine. 2016

[26] Mero A, Campisi M, Caputo M, Cuppari C, Rosato A, Schiavon O, Pasut G. Hyaluronic Acid as a Protein Polymeric Carrier: An Overview and a Report on Human Growth Hormone. Curr Drug Targets. 2015;16(13):1503-11. doi: 10.2174/1389450116666150107151906. PMID: 25563593.

[27] Cosco D, Mare R, Paolino D, Salvatici MC, Cilurzo F, Fresta M. Sclareol-loaded hyaluronan-coated PLGA nanoparticles: Physico-chemical properties and in vitro anticancer features. Int J Biol Macromol. 2019 Jul 1;132:550557. doi: 10.1016/j.ijbiomac.2019.03.241. Epub 2019 Apr 1. PMID: 30946903.

[28] La Mendola D, Magrì A, Santoro AM, Nicoletti VG, Rizzarelli E. Copper(II) interaction with peptide fragments of histidine-proline-rich glycoprotein: Speciation, stability and binding details. J Inorg Biochem. 2012 Jun;111:59-69. doi: 10.1016/j.jinorgbio.2012.02.027. Epub 2012 Mar 6. PMID: 22484501.

[29] Wakabayashi S. New insights into the functions of histidine-rich glycoprotein. Int Rev Cell Mol Biol. 2013;304:46793. doi: 10.1016/B978-0-12-407696-9.00009-9. PMID: 23809442.

[30] Magrì, A.; Grasso, G.; Corti, F.; Finetti, F.; Greco, V.; Santoro, A. M.; Sciuto, S.; La Mendola, D.; Morbidelli, L.; Rizzarelli, E., Peptides derived from the histidine-proline rich glycoprotein bind copper ions and exhibit antiangiogenic properties. Dalton Transactions 2018, 47 (28), 9492-9503.

[31] Almalik, A.; Benabdelkamel, H.; Masood, A.; Alanazi, I. O.; Alradwan, I.; Majrashi, M. A.; Alfadda, A. A.; Alghamdi, W. M.; Alrabiah, H.; Tirelli, N.; Alhasan, A. H., Hyaluronic Acid Coated Chitosan Nanoparticles Reduced the Immunogenicity of the Formed Protein Corona. Scientific Reports 2017, 7 (1).

[32] Lanza V, Greco V, Bocchieri E, Sciuto S, Inturri R, Messina L, Vaccaro S, Bellia F, Rizzarelli E. Synergistic effect of L-Carnosine and hyaluronic acid in their covalent conjugates on the antioxidant abilities and the mutual defense against enzymatic degradation. Accepted in Antioxidant MDPI 2022.

[33] Navarro, J. R. G.; Werts, M. H. V., Resonant light scattering spectroscopy of gold, silver and gold-silver alloy nanoparticles and optical detection in microfluidic channels. The Analyst 2013, 138 (2), 583-592.

[34]Kundu, S., Gold Nanoparticles: Their Application as i Antimicrobial Agents and Vehicles of Gene Delivery. Advances in Biotechnology \& Microbiology 2017, 5.

[35] Cheng, M. J.; Prabakaran, P.; Kumar, R.; Sridhar, S.; Ebong, E. E., Synthesis of Functionalized 10-nm Polymercoated Gold Particles for Endothelium Targeting and Drug Delivery. J Vis Exp 2018, (131), 56760.

[36] Mavani, K.; Shah, M., Synthesis of Silver Nanoparticles by using Sodium Borohydride as a Reducing Agent. 2013.

[37] Polte, J.; Ahner, T. T.; Delissen, F.; Sokolov, S.; Emmerling, F.; Thunemann, A. F.; Kraehnert, R. J. Am. Chem. Soc. 2010, 132, 1296.

[38] Haiss W, Thanh NT, Aveyard J, Fernig DG. Determination of size and concentration of gold nanoparticles from UVvis spectra. Anal Chem. 2007 Jun 1;79(11):4215-21. doi: 10.1021/ac0702084. Epub 2007 Apr 26. PMID: 17458937.

[39] Sanfilippo V, Caruso VCL, Cucci LM, Inturri R, Vaccaro S, Satriano C. Hyaluronan-Metal Gold Nanoparticle Hybrids for Targeted Tumor Cell Therapy. Int J Mol Sci. 2020 Apr 27;21(9):3085. doi: 10.3390/ijms21093085. PMID: 32349323; PMCID: PMC7247672.

[40]F. Gołek, P. Mazur, Z. Ryszka, S. Zuber, AFM image artifacts, Applied Surface Science, Volume 304, 2014, Pages 11-19, ISSN 0169-4332, https://doi.org/10.1016/j.apsusc.2014.01.149.

[41] M7-A7, METHODS FOR DILUTION ANTIMICROBIAL SUSCEPTIBILITY TESTS FOR BACTERIA THAT GROW AEROBICALLY. Clinical Laboratory Standards Institute 2006.

[42] Inturri R, Trovato L, Volti GL, Oliveri S, Blandino G. In vitro inhibitory activity of Bifidobacterium longum BB536 and Lactobacillus rhamnosus HN001 alone or in combination against bacterial and Candida reference strains and 
clinical isolates. Heliyon. 2019 Nov 22;5(11):e02891. doi: 10.1016/j.heliyon.2019.e02891. PMID: 31799467; PMCID: PMC6881622.

[43]Clinical and Laboratory Standards Institute, Performance Standards for Antimicrobial Susceptibility Testing; Twenty-Third Informational Supplement, M100-S23, Clinical and Laboratory Standards Institute, Wayne, PA, 2013.

[44] Koob TJ, Lim JJ, Massee M, Zabek N, Rennert R, Gurtner G, Li WW. Angiogenic properties of dehydrated human amnion/chorion allografts: therapeutic potential for soft tissue repair and regeneration. Vasc Cell. 2014 May 1;6:10. doi: 10.1186/2045-824X-6-10. PMID: 24817999; PMCID: PMC4016655.

[45] Wuensch E, Heidrich HG. On the quantitative determination of collagenase. Hoppe Seylers Z Physiol Chem. 1963;333:149-151.

[46] Di Pasquale R, Vaccaro S, Caputo M, Cuppari C, Caruso S, Catania A, Messina L. Collagenase-assisted wound bed preparation: An in vitro comparison between Vibrio alginolyticus and Clostridium histolyticum collagenases on substrate specificity. Int Wound J. 2019 Aug;16(4):1013-1023. doi: 10.1111/iwj.13148. Epub 2019 May 31. PMID: 31148413; PMCID: PMC7948778. 